discoveries are cruciform rooms, of which the floors are covered with red paint; and among the artefacts are a number of bead-collars. Of even greater importance for the archæologist is a pair of solid gold boots, nearly two inches high, of exquisite workmanship. With two doubtful exceptions, objects of worked gold have not been found hitherto in that period of the Maya civilisation to which the ruins of Copan are assigned. Unless further and more intensive study should point to a foreign origin, these boots of gold must be accepted as evidence that the Maya added no little skill in this technique to their artistic accomplishment, and that a neglect of goldworking, which has always seemed somewhat surprising, has been attributed to them in error. Further details of the stone statues and monoliths will be awaited by archæologists with the greatest interest, as owing to the conditions of discovery, they should throw further light on the development of the Maya art of stone carving, for which the site of Copan is already remarkable among Maya remains.

Copan, situated in the modern State of Honduras, lies in what was the southern area of Maya occupation, and was the fourth city to be founded after they had entered the country. It belongs to the 'Old Empire' or early Maya period and was occupied in at least the period from 195 A.D. until 540 A.D. This minimum period is derived from Mayan dates carved on stelæ found on the site, which are correlated with the Christian era according to a generally accepted interpretation. Copan is one of the most extensive and important of Maya sites. Its ruins consist of a vast complex of buildings which were reconstructed time and again in the course of occupation. Structural remains cover nearly the whole of the Copan valley. Recently, however, the site has suffered much from the effects of earthquake, and the river has begun to encroach on important parts of the ruins. In the circumstances, the Mexican Government has asked for the assistance of the Carnegie Institution's Expedition, which has had its headquarters at Chichen Itzé in Yucatan for some years and has had much experience in the restoration and preservation of Maya structures. Of this co-operation the present discovery is an outcome. Dr. Stronsvik reports, according to a communication issued by Science Service, Washington, that a part of the bank has collapsed into the river, and a beautifully carved chamber excavated fifty years ago by the late A. P. Maudslay, the well-known British archæologist, has fallen in. The landslide has left a vertical section of the ruins about a hundred feet in height on the eastern side. Dr. Stronsvik is of the opinion that the Maudslay chamber can be reconstructed, but the material carried away by the river is irrecoverably lost. As a minor mitigation, however, the landslide has revealed an instructive cross-section of the city's development.

\section{Pygmy Man in India}

A Remarkable report has come from Bombay of the diseovery of the fossilised remains of a pygmy man in Baroda State. According to the account from the correspondent of The Times in the issue of February 21, the discovery was made at Vadnagar in the Mehsana district of Baroda. The remains were said to have been found in a prehistoric step-well, $150 \mathrm{ft}$. long, and were those of a man 15 inches high. With them was a cow 18 inches high; nearby was a stick 10 inches high. The correspondent of The Times went on to point out that the discovery might call for a new orientation of theories concerning the cradle of the human race and the origin of civilisation which would no longer be traced to Java, or the valley of the Nile or the Indus, but rather to the valley of the Narmada. He also referred to Homer's story of the battle of the dwarfs and cranes and the report of Ctesias in the fifth century B.c. of the existence of a dwarf race in the heart of India. Even if the report were taken seriously-it has been stated to be a hoax-the discovery of a single specimen of so remarkably an aberrant character would be scant foundation "to prove the existence of an extinct race of pygmies more diminutive than that in Africa". Most ethnologists postulate a negrito strain in the Indian peoples which may have been derived from a diminutive race, not of some unknown extinct form, but analogous to one of the pygmy peoples, which extend, with intermissions, from West Africa to New Guinea; but these peoples are a highly specialised rather than a primitive type and their stature does not, as a rule, fall much below four feet six inches. Ethnological theory, for the moment, remains unshaken.

\section{High-Altitude and Long-Distance Flights}

The Air Ministry has recently authorised the construction of two new experimental aeroplanes, one for high-altitude and the other for long-distance flights. The high-altitude machine will presumably be used for exploring the question of flight in the stratosphere, which is usually taken to mean that region in space above a height of 28,000 feet. There are plenty of aircraft in existence capable of reaching heights greater than this; the present record is 47,356 ft. held by the Italian pilot Donati, but no attempt has yet been made to deal with the possibilities of economical flight at such heights. The ultimate possibilities in this respect are much greater speeds owing to the reduced resistance of the rarified air. It will be necessary to carry superchargers to supply the required oxygen for the combustion of the engine fuel, appliances for breathing and heating, air-tight cabins or special suits for the occupants, and propellers the pitch of which can be changed to suit the different air conditions. These extras will have weight, which will reduce the fuel-carrying capacity of the machine, and it is not impossible that this requirement alone will limit the practical utility of stratosphere flying.

THE time taken to climb to such heights will be considerable, which will possibly make the proposition not worth while except for long flights, where again lack of fuel capacity will place a limit on it. Such flights are not likely to have any immediate application to air transport, but their importance in the experimental sense is obvious. The long-range 